\title{
Reliability of partially encased steel-concrete composite columns under eccentric loading
}

\section{Confiabilidade de pilares mistos aço-concreto parcialmente revestidos em flexo-compressão}
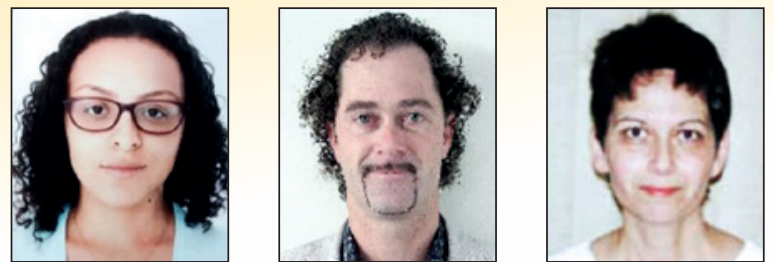

M. F. PEREIRA a margot.fabiana@gmail.com

A. T. BECK a atbeck@sc.usp.br

A. L. H. C. EL DEBS a analucia@sc.usp.br

\begin{abstract}
The Brazilian design code for composite buildings (NBR8800) has never been subject to a reliability-based calibration of the partial factors used in design. As a consequence, the level of structural safety achieved by using these factors is, in general, unknown. This paper presents a study of the reliability of partially encased steel-concrete composite columns, subject to compression and bending. Literature statistics are used to quantify uncertainty in strength of structural materials and in loads. Reliability indexes are evaluated, via FORM, for two ratios between dead and live loads, and for some values of load eccentricity. It was found that larger load eccentricity leads to a reduction in reliability indexes. These values are larger than minimum values recommended in international design codes; hence one concludes that design of such columns using NBR8800 leads to acceptable safety levels.
\end{abstract}

Keywords: reliability, composite column, structural safety.

\section{Resumo}

A norma brasileira que embasa o projeto estrutural de edifícios contendo elementos mistos (NBR8800) nunca passou pelo processo de calibração, baseada em confiabilidade, dos coeficientes parciais de segurança utilizados em projeto. Como consequência, o nível de segurança obtido com o uso destes coeficientes é, em geral, desconhecido. Este trabalho apresenta um estudo da confiabilidade estrutural de pilares mistos de aço-concreto, parcialmente revestidos e submetidos à flexo-compressão. Estatísticas da literatura são utilizadas para caracterizar as incertezas nas propriedades dos materiais constituintes e nas ações. Índices de confiabilidade ( $\beta$ ) são avaliados, via FORM, para duas razões entre ação permanente e ação variável, e para alguns valores de excentricidade da ação vertical. Verifica-se que o índice de confiabilidade dos pilares mistos diminui com o aumento da excentricidade de projeto. Estes valores estão acima de índices de confiabilidade mínimos sugeridos em normas internacionais, o que sugere que o projeto utilizando a norma NBR8800 resulta em colunas mistas seguras.

Palavras-chave: confiabilidade; pilares mistos; segurança estrutural.

Universidade de São Paulo, Departamento de Engenharia de Estruturas, Escola de Engenharia de São Carlos, São Carlos, SP, Brasil. 


\section{Introduction}

The demand for fast and economical constructive systems in engineering pushes the advancement of composite structures such as steel-concrete composites. In comparison to usual reinforced concrete, steel-concrete composite construction reduces or eliminates the need for form-work, reduces material consumption and workmanship, and increases dimensional precision of structural elements. Fabrication of steel-concrete composites can be industrialized, with elements assembled in place at the construction site. In spite of the benefits above, lack of deeper knowledge by design engineers restricts greater employment. Only in 2008, steelconcrete composite construction was normalized in Brazil, with the advent of NBR 8800 [1].

Modern codes for the design of buildings are based on limit states, where partial safety factors are used to establish an appropriate margin of safety w.r.t. each of the main sources of uncertainty in design: the structural loads, and the strength of materials. Partial safety factors ensure an adequate level of safety for the designed structures. However, Brazilian design codes have never been subject to the process of reliability-based calibration of partial safety factors, as the equivalent foreign codes (ACI 318 [2], EN 1992 [3], EN 1994 [4], FIB [5]). The calibration process for NBR 8800 was studied in [6], but the suggested safety factors were never incorporated in the actual code. In the specific case of composite structures, only isolated evaluations of safety factors are found in the literature [7-11]. The main objective of this work is to study the safety of partially-encased steel-concrete composite columns (Figure 1), submitted to compressive bending, and designed according to NBR 8800 [1].

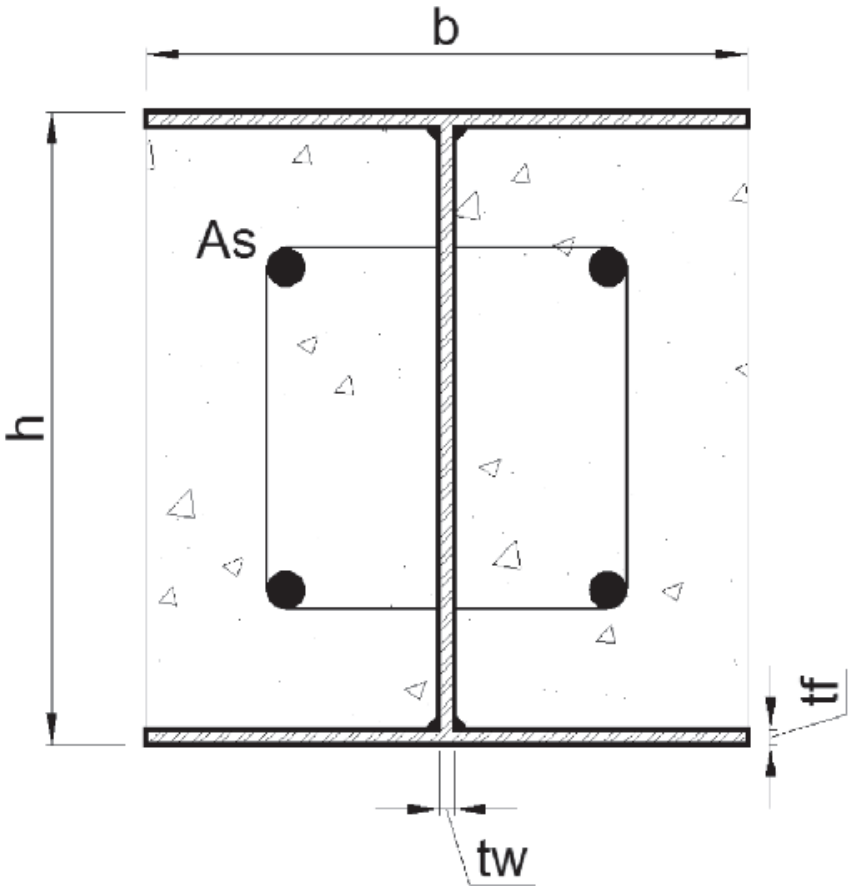

Figure 1

Cross-section of partially encased steel-concrete composite column
Table 1

Concrete mix designs used in the study

\begin{tabular}{|c|c|c|c|}
\hline \multicolumn{3}{|c|}{ Strength } & \multirow{2}{*}{$\begin{array}{c}\text { Load } \\
\text { combination } \\
\text { Dead (D) }+ \\
\text { Sive (L) } \\
1,40 D+1,5 \mathrm{~L}\end{array}$} \\
\hline 1,1 & 1,4 & 1,15 & Reinforcement \\
\hline
\end{tabular}

\section{Design codes for steel and concrete buildings}

Design of steel-concrete composite elements using NBR 8800 [1] is based on safety criteria defined in NBR 8681 [12] and employs design loads defined in specific codes [13]. Design codes for buildings in Brazil use the limit state method, where partial safety factors are employed to warrant minimal safety levels during the useful life of the structure. Hence, for each undesirable state of the structure, either in terms of serviceability or ultimate failure, one limit state function is written. Based on limit states, design equations are written, such as:

$$
R_{d} \geq S_{d}
$$

where:

$R_{d}$ represents the design strength;

$S_{d}$ represents the effects of design loads.

Design values for loads and strengths are obtained from representative (characteristic or nominal) values, which are multiplied by partial safety factors. Load effects have to be evaluated, considering the influence of all loads with significate effects [1], in load combinations which have non-negligible probability of occurring simultaneously (Table 1).

Following NBR 8800 [1], the capacity of composite columns subject to combined compression bending, w.r.t. one or two symmetry axes, can be evaluated in two ways: Model I is the most precise, Model II is the simplified version. Both models consider interaction diagrams, which simplify the real bending moment versus axial load interaction diagram.

Model I is similar to the model for isolated steel columns, adding to it only the influence of concrete between the flanges of the steel beam. The interaction diagram between axial load and bending moment is composed of two straight lines, as illustrated in Figure 2a. In Model II (Figure 2b), the interaction diagram is composed of three straight lines, similar to EUROCODE 4 [4]. In both models, geometrical non-linearity is considered by adding a complementary bending moment, due to geometrical imperfections.

The main equations for designing composite columns according to NBR 8800 [1] are presented in this section. Details can be found in [1]. The strength of composite columns is given by:

$N_{R d}=\chi(\lambda) \mathrm{n}\left(\frac{f_{y} \mathrm{n} A_{a}}{\gamma_{a}}+\alpha_{1} \frac{f_{c} \mathrm{n} A_{c}}{\gamma_{c}}+\frac{f_{s} \mathrm{n} A_{s}}{\gamma_{s}}\right)$ 
where $f_{y}$ is the steel tensile yield strength, $f_{c}$ is the concrete compressive strength, $f_{s}$ is the reinforcement steel tensile yield strength, $A_{a}, A_{c}$ e $\mathrm{A}_{s}$ are the cross-sectional areas of the steel beam, the concrete block and the reinforcement steel, respectively. Partial safety coefficients on structural steel, concrete and reinforcement are given by $\gamma_{\mathrm{a}}, \gamma_{\mathrm{c}}$ and $\gamma_{\mathrm{s}}$, respectively. Coefficient $\alpha_{1}$ is a constant value, given as 0.85 for partially encased steel-concrete composite columns. Factor $\chi(\lambda)$ takes into account the slenderness factor of the column $(\lambda)$, and is given by:

$\chi(\lambda)= \begin{cases}0,658, \lambda^{\lambda^{2}} & \text { if } \lambda \leq 1,5 \\ \frac{0,877}{\lambda^{2}}, & \text { if } \lambda \geq 1,5\end{cases}$

In this work, Model II of NBR 8800 [1] is used. The interaction diagram for Model II is given by:

$$
\frac{M_{x, t o t, S d}}{\mu_{x} M_{c, x}}+\frac{M_{y, t o t, S d}}{\mu_{y} M_{c, y}} \leq 1,0
$$

where $\mu_{x}$ and $\mu_{y}$ represent interaction factors between bending moment and axial load. For each of the considered axes, one has $M_{c}=0,9 M_{p l, R d}$, where $M_{p l, R d}$ is given by:

$$
\begin{aligned}
& M_{p l, R d}=f_{y d}\left(Z_{a}-Z_{a n}\right)+0,5 f_{c d 1}\left(Z_{c}-Z_{c n}\right)+ \\
& f_{s d}\left(Z_{s}-Z_{s n}\right)
\end{aligned}
$$

When employing these models, one has to respect the codespecified limits of applicability, such as double-symmetric crosssections, and other items described in Table 2. For situations out of this scope, EUROCODE 4 [4] presents a general design methodology.

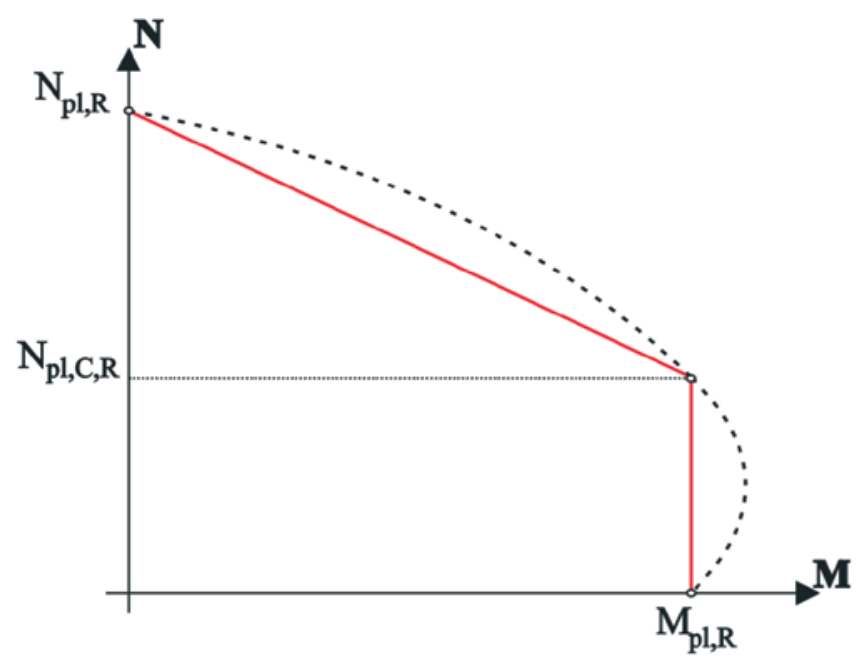

Table 2

Application limits of NBR 8800

\begin{tabular}{|c|c|}
\hline Item & Recommendation \\
\hline Column slenderness $\lambda$ & $\lambda<2,0$ \\
\hline Cross-section aspect ratio & $0,2 \leq \frac{h_{c}}{b_{c}} \leq 5,0$ \\
\hline Local instability & $\frac{b_{f}}{t} \leq 1,49 \sqrt{\frac{E}{f_{y}}}$ \\
& partially encased columns \\
\hline
\end{tabular}

\section{Analysis method}

The strength of a steel-concrete composite column depends on the strengths of the composing materials, as well as on geometrical crosssectional characteristics, both associated to physical uncertainty. In this paper, we denote by $\boldsymbol{X}_{R}$ the vector that contains the random variables which affect strength of the column. These variables are assumed time-invariant, i.e, strength degradation in time is not considered. For a given realization $\boldsymbol{x}_{R}$, and for a specified load eccentricity, column strength is obtained from the interaction curve, which yields axial and bending loads capacities (resistance). The actual interaction curve is parabolic in shape, but following Model II of NBR 8800 , the parabolic capacity curve is approximated by three straight lines, as shown in Figure 2.

\subsection{Limit state equations}

In this paper, we use an adaptation of the method developed by Hong \& Zhou [14] for reinforced concrete columns. The axial capacity of the composite column is written as $P_{R}=p_{R}\left(X_{R}\right)$, and

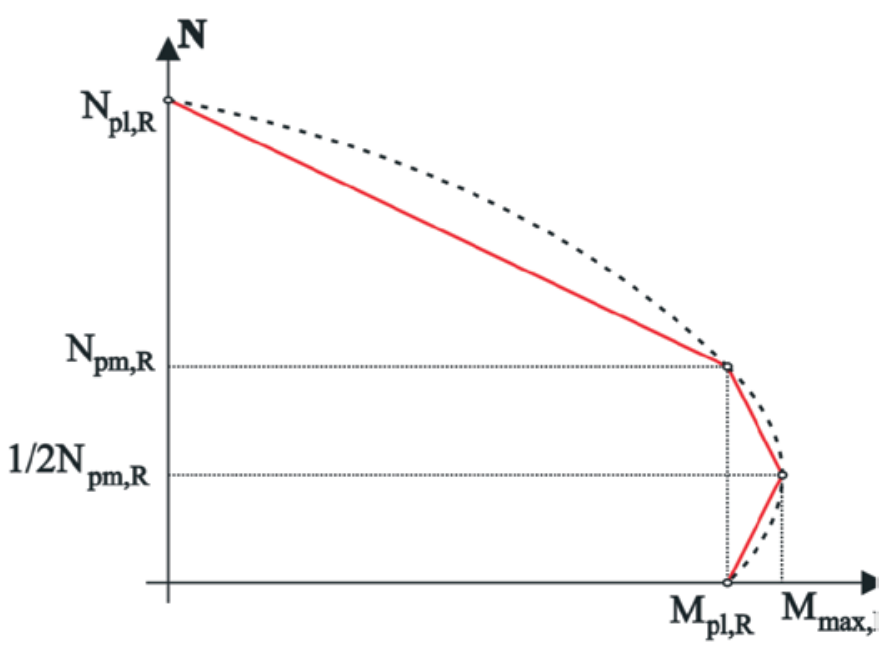

Figure 2

Axial load $x$ bending moment interaction curves for a) Model I and b) Model II (4) 


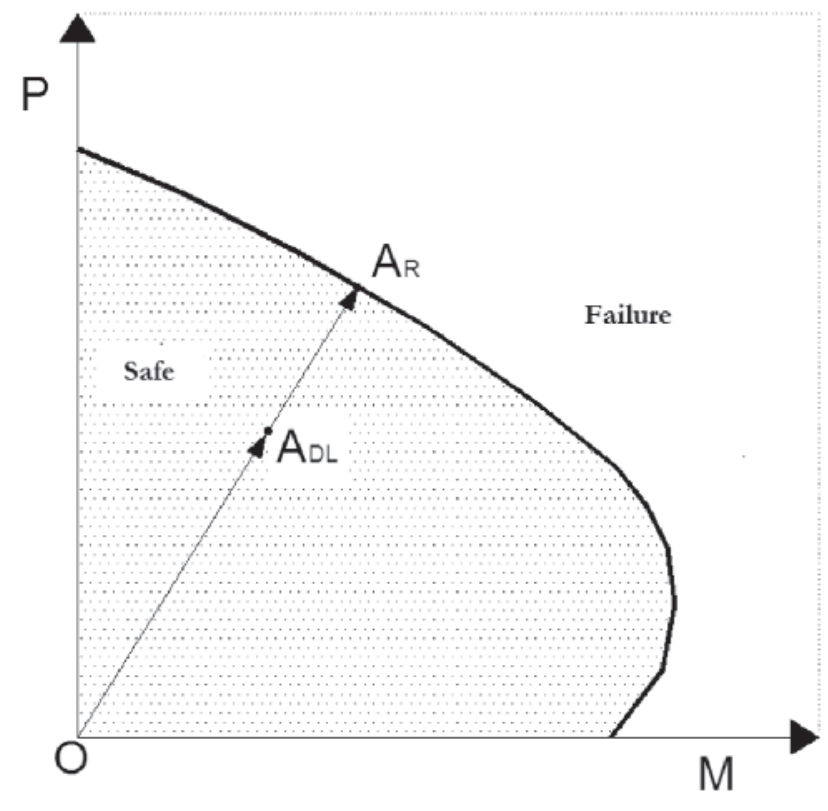

a)

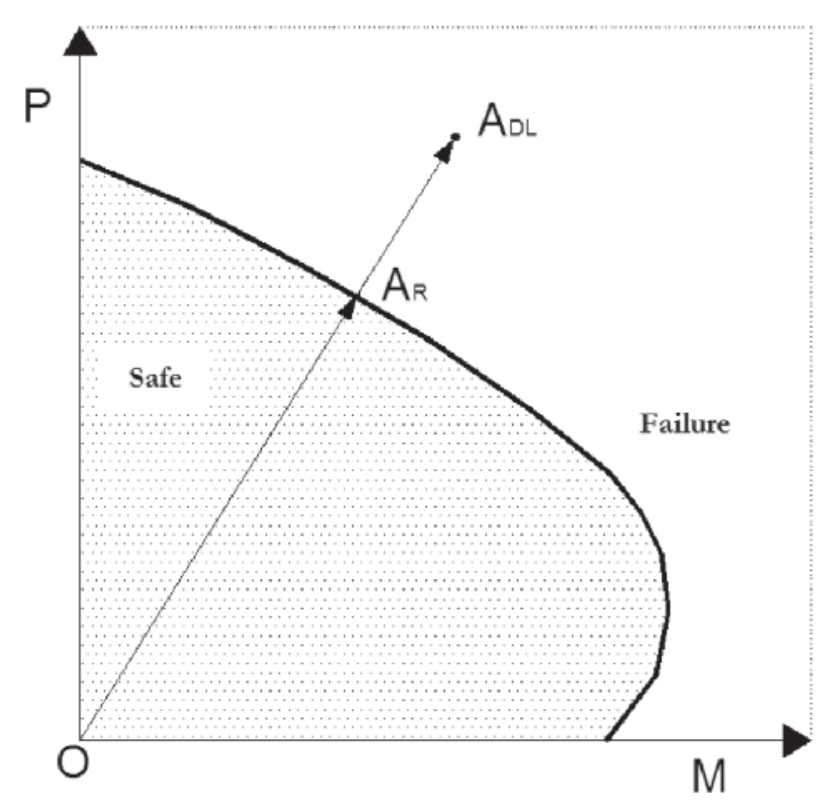

b)

\section{Figure 3}

Interaction diagrams and limit state functions for eccentric column loading

the bending moment capacity is $M_{R}=m_{R}\left(X_{R}\right)$. The ordinated pairs $A_{R}=\left(P_{R}, M_{R}\right)$ form a curve that separates the survival and failure domains.

We denote by $X_{D L}$ the vector containing the load effects acting on the column. Dead $(D)$ and live loads $(L)$ are considered, such that $X_{D L}=\left\{D, L, M_{D}, M_{L}\right\} . M_{D}$ and $M_{L}$ represent the bending moments resulting from dead and life loads, respectively. Hence, for a given eccentricity, point $A_{D L}$, is the combined effect of axial load and bending moment, for all actions. In this setting, failure occurs when the segments $\overline{O A_{D L}}>\overline{O A_{R}}$, that is, when vector $A_{D L}$ enters the failure domain (Figure 3 ).

With these preliminaries, the limit state equation $g\left(X_{R}, X_{D L}\right)$ can be written by comparing the segments $\overline{O A_{R}}$ and $\overline{O A_{D L}}$ :

$$
\begin{aligned}
& g\left(X_{R}, X_{D L}\right)=\left[P_{R}^{2}+\left(M_{R} / h\right)^{2}\right]^{1 / 2}- \\
& {\left[(D+L)^{2}+\left(\left(M_{D}+M_{L}\right) / h\right)^{2}\right]^{1 / 2}}
\end{aligned}
$$

The failure probability can be evaluated by means of well-known methods such as FORM, SORM or Monte Carlo Simulation. The First Order Reliability Method (FORM) is used in this paper.

\subsection{Model error}

One relevant source of uncertainty in structural reliability problems is the model error. This is a measure of the ratio between the strength of a structural element, a given by a simplified calculation model, and the actual strength, as tested. For steel-concrete composite columns under centric axial load, some information on mod- el errors exist [7, 8, 14]. However, our literature survey resulted in no such results for eccentric loading.

Some experimental results obtained by the authors, regarding compressive-bending of short and slender columns, have shown that the NBR 8800 [1] model is quite conservative, especially for large slenderness columns. Figure 4 illustrates the capacity of intermediate-slender and short columns, in comparison with the code model. The experimental results are close to the theoretical model, and show small variability. The NBR 8800 models are

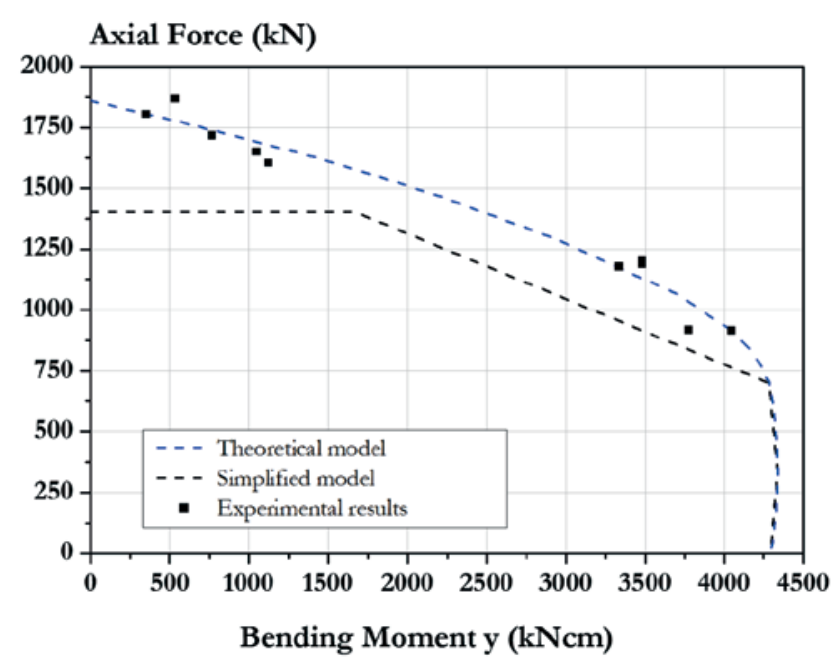

Figure 4

Experimental results and design curves following NBR 8800 
Table 3

Cross-section characteristics of studied column

\begin{tabular}{|c|c|c|c|c|}
\hline Variable & Nominal & Mean/nominal & COV & Distribution \\
\hline Concrete compressive strength $\mathrm{f}_{\mathrm{c}}$ & $50 \mathrm{MPa}$ & 1.2 & 0.12 & Normal \\
\hline Steel yield strength $\mathrm{f}_{\mathrm{y}}$ & $300 \mathrm{MPa}$ & 1.2 & 0.04 & Normal \\
\hline Reinforcing steel yield strength $\mathrm{f}_{\mathrm{s}}$ & $600 \mathrm{MPa}$ & 1.0 & - & Deterministic \\
\hline Steel elasticity modulus $\mathrm{E}$ & $200 \mathrm{GPa}$ & 1.0 & - & Deterministic \\
\hline Cross-section height $\mathrm{h}$ & $152 \mathrm{~mm}$ & 1.0 & - & Deterministic \\
\hline Flange width $\mathrm{b}$ & $152 \mathrm{~mm}$ & 1.0 & - & Deterministic \\
\hline Web thickness $t_{w}$ & $5.8 \mathrm{~mm}$ & 1.0 & - & Deterministic \\
\hline Flange thickness $t_{f}$ & $6.6 \mathrm{~mm}$ & 1.0 & - & Deterministic \\
\hline Reinforcement area & $2.01 \mathrm{~cm}^{2}$ & 1.0 & - & Deterministic \\
\hline
\end{tabular}

conservative w.r.t. experimental results, especially the model that takes imperfections into account. With this limited analysis, we intend to show that the NBR 8800 model presents small bias and small variability; hence the effect of such a model error in the following reliability analysis is limited. Due to the small number of tested specimens, however, it was not possible for us to obtain a statistical characterization of the NBR 8800 model error for eccentrically loaded steel-concrete composite columns.

\section{Numerical analyses and results}

The reliability of steel-concrete composite columns was investigated, with column cross-section as presented in Figure 1. The reduced slenderness factor is 0.41 . Geometrical and mechanical characteristics of the studied column are presented in Table 3: characteristic concrete strength is $50 \mathrm{MPa}$, and reinforcement is CA-50. Table 3 also presents the statistical data on the considered random variables. The following is also relevant:

a) Uncertainties associated to cross-section dimensions were disconsidered, as their effects on structural safety are generally small;

b) The data shown in Table 3 was obtained either by actual testing or taken from the literature [15].

In the usual design condition, the structural element is designed to support a specified load. In the current reliability analysis, however, it is easier but equivalent to adopt an inverse procedure: given a cross-section and slenderness, the admissible loading is designed following code specifications (Eq. 1). The same admissible loading can be obtained from different ratios between dead and live loads, hence the life-to-dead load ratio $\left(\alpha=L_{n} / D_{n}\right)$ also has to be defined. So-called heavy structures have $(\alpha<<1.0)$, whereas light structures

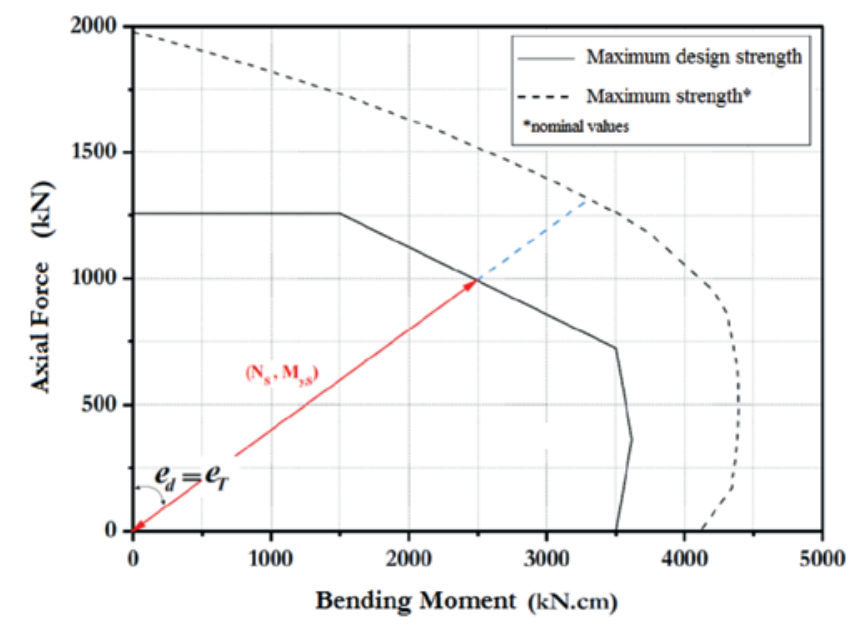

(a)

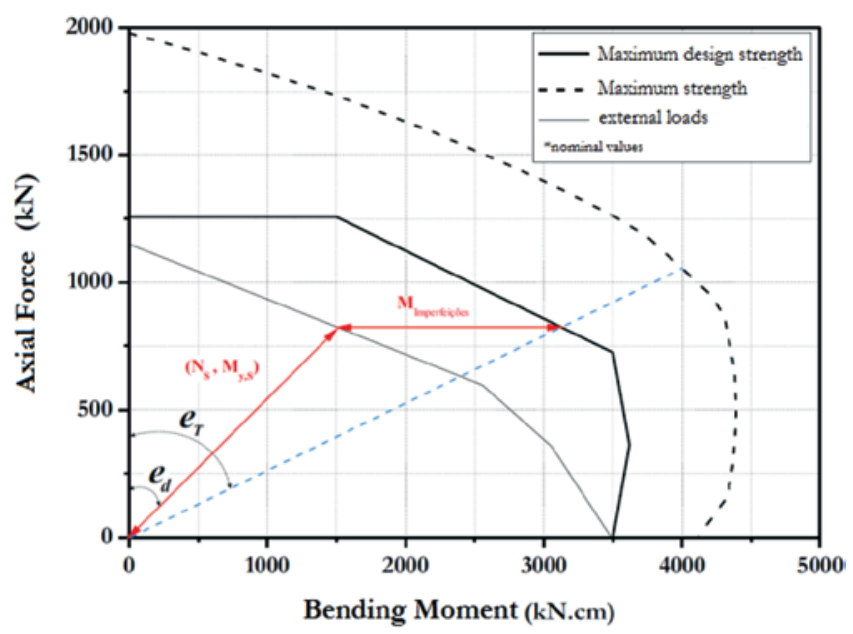

(b)

Figure 5

Analysis strategies A) - without - and B) with - consideration of additional eccentricity due to column imperfections 
Table 4

Characterization of random loading (16)

\begin{tabular}{|c|c|c|c|c|}
\hline Variable & Nominal & $\begin{array}{c}\text { Mean/ } \\
\text { nominal }\end{array}$ & CoV Distribution \\
\hline Axial dead load & 1.03 & 0.08 & Normal & Normal \\
\hline Bending moment due to dead load & 1.03 & 0.08 & Normal & Normal \\
\hline Axial live load (50-year extreme) & 1.00 & 0.18 & Gumbel Deterministic \\
\hline Bending moment due to life load (50-year extreme) & 1.00 & 0.18 & Gumbel & Deterministic \\
\hline
\end{tabular}

have $(\alpha \geq 1.0)$. In this paper, two life-to-dead load ratios are considered, $\alpha=0.25$ and $\alpha=1.0$. Since eccentric loading is considered, the same ratio is admitted between nominal values of bending moments $\left(M_{D n}\right.$ and $\left.M_{L n}\right)$.

The design eccentricity is given by:

$e_{\text {design }}=\frac{\left(1,4 M_{D n}+1,5 M_{L n}\right)}{\left(1,4 D_{n}+1,5 L_{n}\right)}$
With the cross-section, the load ratio and the design eccentricity specified, one finds the nominal values of loading variables $\left(D_{n}, L_{n}\right.$, $M_{D n}$ and $\left.M_{L n}\right)$. From the nominal loads, the probability distributions of random loads are re-constructed (Tabela 4), following Nowak [16].

The existence of correlation between axial loads $\left(D_{n}\right.$ and $\left.L_{n}\right)$ and bending moments $\left(M_{D n}\right.$ and $\left.M_{L n}\right)$ is not fully addressed in the literature. Clearly, there is some positive correlation, because bending moments are in part caused by load eccentricity. However, correlation is not perfect, because bending moments are also caused by

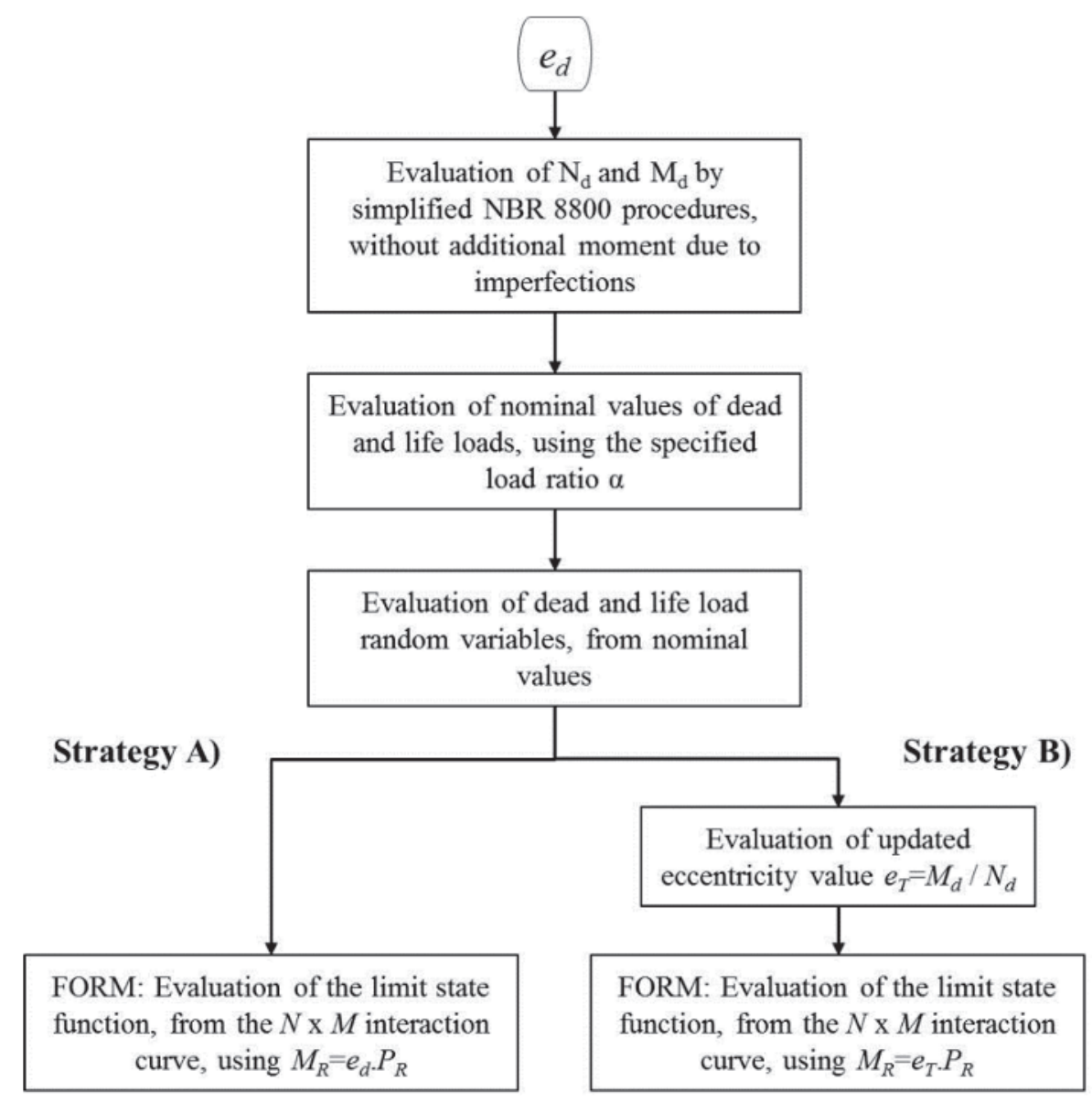

Figure 6

Fluxograms for analysis strategies: a) A and b) B 

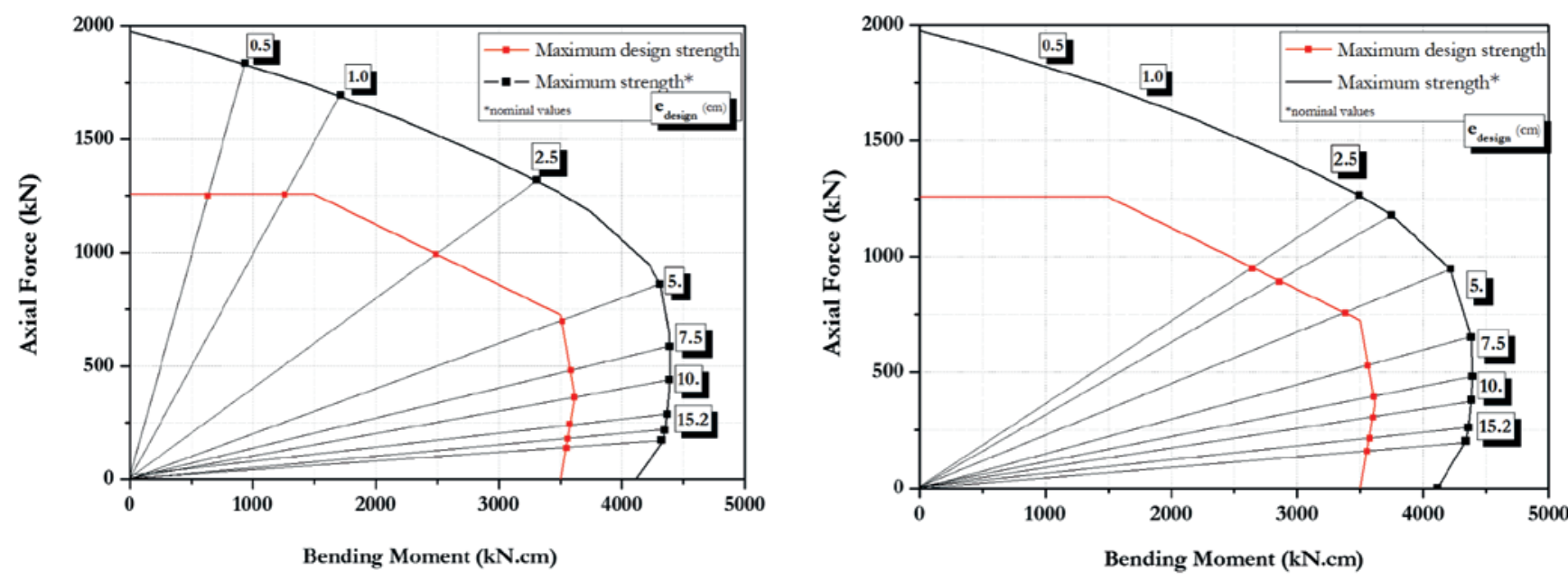

(a)

(b)

\section{Figure 7}

Axial load $x$ versus bending moment diagrams for analysis strategies: a) $A$ and b) $B$

straightness imperfections, for instance. In this work, we assume a linear correlation coefficient of 0.5 .

The analysis procedure is based in Hong and Zhou [4], and is given in four steps:

1. Determination of design values for axial loads and bending moments, following Table 3, using two procedures based on Model II of NBR 8800: Strategy A), without consideration of imperfections; Strategy B) considering additional moments due to imperfections [1] (Figure 5);

2. Evaluation of nominal load values $\left(L_{n}, D_{n}, M_{L n}\right.$ and $\left.M_{D n}\right)$, for the chosen load ratio $\alpha$, and using Table 1 ;

3. Construction of loading random variables, from nominal values (step 2), and using Table 4;

4. Evaluation of reliability indexes by FORM and Eq. (6).

The procedure is illustrated by a fluxogram in Figure 6 .

Figure 7 shows, for the two strategies considered in this work, the normal force $\mathrm{x}$ bending moment interaction diagrams for the studied column. The curve "Maximum design strength" presents ordinated pairs obtained in Step 1, for different values of design eccentricity, but reduced by the partial safety coefficients. The curve

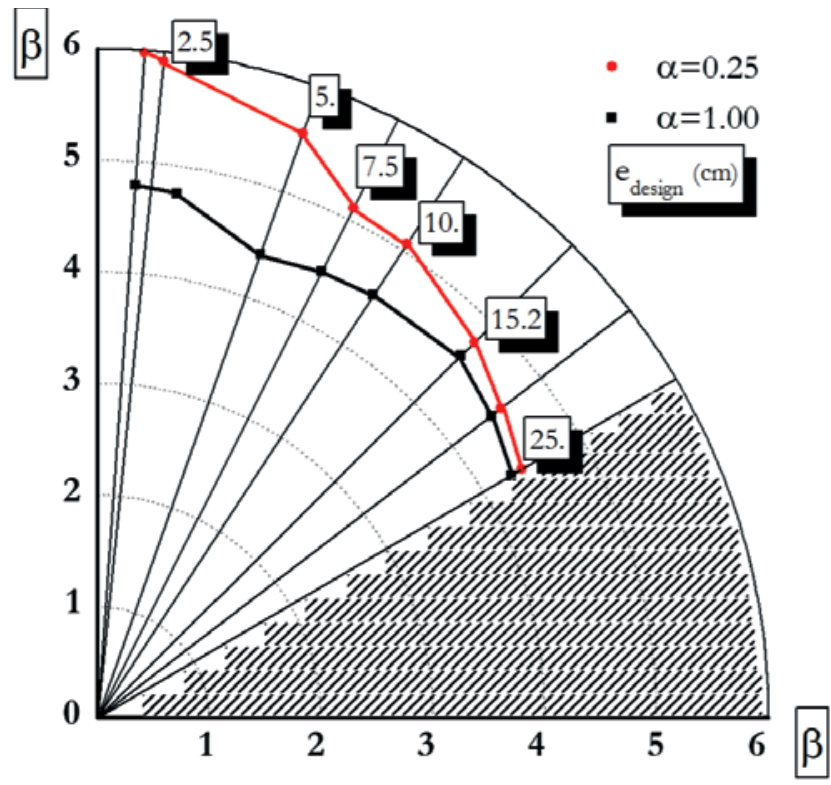

(a)

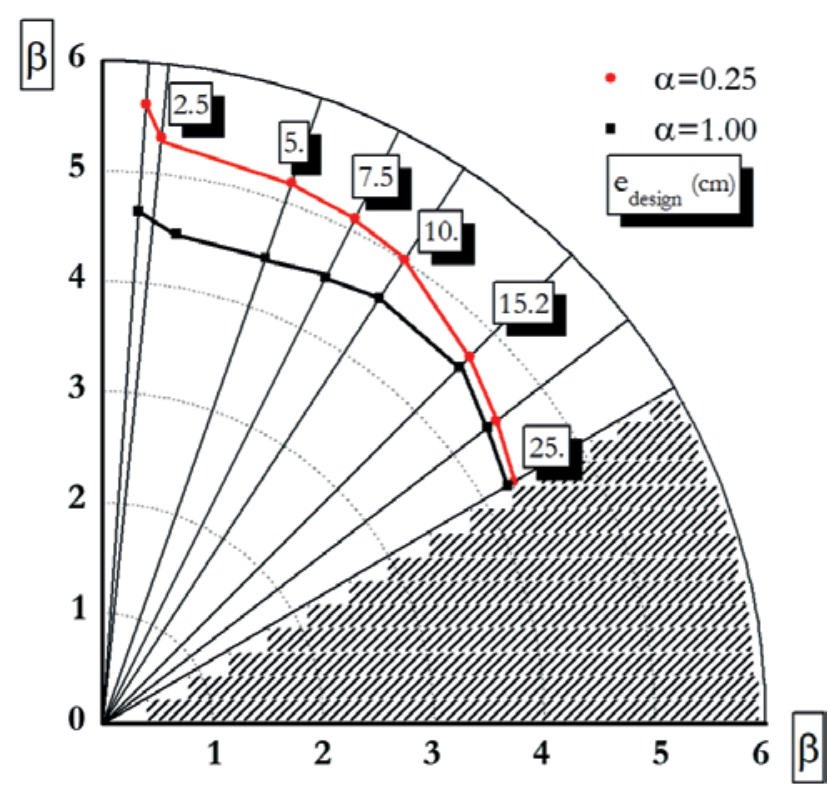

(b)

Figure 8

Reliability index diagrams for analysis strategies: a) A and b) B 
Table 5

Reliability indexes $\beta$

\begin{tabular}{|c|c|c|c|c|c|}
\hline \multirow{2}{*}{$\begin{array}{c}\text { Design } \\
\text { eccentricity }\end{array}$} & \multirow{2}{*}{$\begin{array}{c}\text { Relative } \\
\text { eccentricity }\end{array}$} & \multicolumn{3}{|c|}{ Strategy A } & \multicolumn{2}{|c|}{$\begin{array}{c}\text { Strategy B (with secondary } \\
\text { eccentricity) }\end{array}$} \\
\cline { 3 - 6 } & $\mathbf{e} / \mathbf{h}$ & $\alpha=\mathbf{0 . 2 5}$ & $\alpha=1.00$ & $\alpha=\mathbf{0 . 2 5}$ & $\alpha=1.00$ \\
\hline $\begin{array}{c}\mathbf{e}_{\text {design }} \cdot \mathbf{e}_{\text {design }} \\
\mathbf{c m})\end{array}$ & 0.007 & 5.98 & 4.79 & 5.62 & 4.65 \\
\hline 1.0 & 0.015 & 5.92 & 4.75 & 5.33 & 4.48 \\
\hline 2.5 & 0.035 & 5.55 & 4.40 & 5.18 & 4.46 \\
\hline 5.0 & 0.050 & 5.11 & 4.48 & 5.11 & 4.51 \\
\hline 7.5 & 0.065 & 5.07 & 4.52 & 5.01 & 4.59 \\
\hline 10.0 & 0.100 & 4.76 & 4.59 & 4.69 & 4.56 \\
\hline 15.2 & 0.165 & 4.40 & 4.44 & 4.31 & 4.25 \\
\hline 25.0 & & & & & \\
\hline
\end{tabular}

"Maximum strength" represents the nominal values that this ordinated pair could achieve without partial safety factors. In Strategy B), the additional eccentricity due to imperfections is considered, leading to a total eccentricity.

Reliability indexes $\beta$ obtained for two load ratios and eigth design eccentricities are shown in Figure 8. One can observe that, for both modelling strategies adopted ( $\mathrm{A}$ and $\mathrm{B}$ ) reliability indexes are of the same order, slightly larger values for the case where additional eccentricities are disconsidered. For both cases, reliability indexes $\beta$ decrease as the design eccentricity increases. Since design procedures are based primarily on axial compression, this result makes sense. In spite of the reliability index reduction for larger eccentricity, results are always above $\beta=4$ (Table 5). These reliability indexes would be a little smaller if model error had been taken into account. Model errors for columns generally vary w.r.t. slenderness $[7,8]$, and we also assume that they would change following load eccentricity.

Results also show that reliability index $\beta$ are reduced when the life-to-dead load ratio $\left(\alpha=\mathrm{L}_{n} / D_{n}\right)$ increases; this is expected, since coefficients of variation of the life load are larger than those for the dead load. Hence, when $\alpha$ is increased, problem uncertainty increases, making reliability indexes smaller.

One of the sub-products of a reliability analysis by FORM are the sensitivity coefficients, which measure the relative contribution of each random variable towards the calculated failure probabilities $\left(\sum\left(\alpha_{i}\right)^{2}=1\right)$. Figure 9 shows sensibility coefficients obtained in analysis Strategy B). It can be observed that the relative contribution of random variables change, as design eccentricity $e_{\text {design }}$ changes. As design eccentricity increases, concrete strength becoming less relevant, and steel reinforcement becomes the relevant variable, with $\alpha_{i}=0,559$ (Figure 9). Similar behavior was observed for Strategy $A)$.

\section{Concluding remarks}

This paper investigated the safety of partially encased steel- concrete composite columns, designed according to NBR 8800 , and submitted to eccentric loading. The safety was evaluated by means of structural reliability theory, having the reliability index as metric. It was found out that:

- Column reliability depends on load eccentricity, and reduces as eccentricity increases;

- When additional load eccentricity due to imperfections was considered, mean reliability indexes $\beta$ were found as 5.03 and 4.50 , for live-to-death load ratios of 0.25 and 1.0 , respectively. When additional eccentricity was disconsidered, reliability indexes were 5.26 and 4.57 , respectively.

- Design of composite columns following NBR8800 leads to acceptable levels of safety, even under significant load eccentricity; model errors, however, were not considered.

- The collection of more experimental data on the strength of composite steel-concrete columns under eccentric loading is recommended, in order to allow for a comprehensive description of model errors.

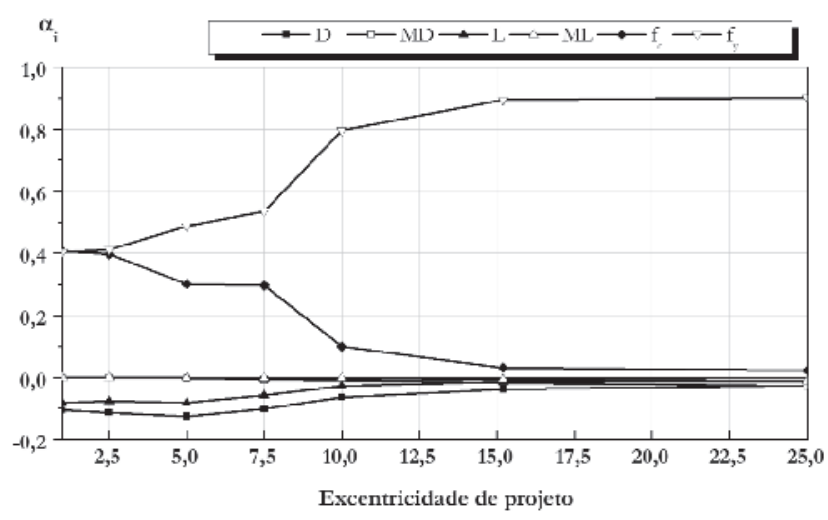

Figure 9

Sensibility factors for random variables in strategy B), $\alpha=0.25$ 


\section{Nomenclature}

$\mathrm{A}_{\mathrm{a}} \quad$ - Steel cross-section area

A _ - Concrete cross-section area

$A_{s} \quad-$ Reinforcing steel cross-section area

$b_{c} \quad-$ Width of concrete cross-section

$b_{\mathrm{f}} \quad-$ Flange width

E - Elasticity modulus for steel

$\mathrm{f}_{\mathrm{cd}} \quad-$ Design strength for concrete in compression

$\mathrm{f}_{\mathrm{yd}} \quad-$ Design strength of steel yielding

$\mathrm{f}_{\mathrm{sd}} \quad$ - Design strength of reinforcement steel yielding

$\mathrm{h}_{\mathrm{c}}$ - Height of concrete cross-section

$\mathrm{M}_{\text {tot, Sd }}$ - Total design bending moments

$\mathrm{M}_{\mathrm{pl}, \mathrm{Rd}}$ - Plastification moment

$\mathrm{N}_{\mathrm{pl}, \mathrm{Rd}}$ - Design axial strength for cross-section plastification

$t \quad$ - Thickness of steel

$\mathrm{Z}$ - Plastic modulus of cross-section

$\lambda \quad-$ Slenderness factor

$\mu \quad-\quad$ Interaction factor

$\mathrm{X} \quad-$ Strength reduction factor due to slenderness

\section{Acknowledgments}

The authors acknowledge funding of this research project by FAPESP - São Paulo State Research Founding Agency (Grant $n^{\circ}$ 2014/12694-0).

\section{References}

[1] Associação Brasileira de Normas Técnicas. NBR 8800: Projeto de estruturas de aço e de estruturas mistas de aço e concreto de edifícios, Rio de Janeiro, 2008.

[2] American Concrete Institute. ACI 318R-95: building code requirements for structural concrete. Farmington Hills; Detroit, 1995.

[3] Comité Européen de Normalisation. EN 1992-1-2: Design of concrete structures. General rules. Structural fire design, Brussels, 2004.

[4] Comité Européen de Normalisation. EN 1994-1-1: Design of composite steel and concrete structures. General rules and rules for buildings, Brussels, 2004.

[5] Comité Euro-international du Béton. CEB-FIB Model Code 1990. London, Thomas Telford, 1993.

[6] Beck AT, Souza Jr. AC, 2010: A first attempt towards reliability-based calibration of Brazilian structural design codes. J. of the Brazilian Society of Mechanical Sciences \& Engineering 32, 119 - 127.

[7] Oliveira WLA, Beck AT, Debs ALHC, 2008: Safety evaluation of circular concrete-filled steel columns designed according to Brazilian building code NBR 8800:2008. IBRACON Structures and Materials Journal 1, 212 - 236.

[8] Beck AT, Oliveira WLA, DeNardim S, EIDebs ALHC, 2009: Reliability-based evaluation of design code provisions for circular concrete-filled steel columns. Engineering Structures 31, 2299-2308.

[9] Vincent R, Tremblay R. "An Innovative Partially Composite Column System for High-Rise Buildings", Proceedings,
North American Steel Construction Conf., Fort Lauder-lade, Florida, 30-3 - 30-17, 2001.

[10] Chicoine T, Tremblay R, Massicotte B. "Long-term Behavior and Strength of partially encased composite columns made with built-up steel shapes", Journal of Structural Engineering, Canada, 129(2), 141-150, 2003.

[11] Tremblay R, Chicoine T, Massicotte B. "Design equation for the capacity of partially encased non-columns" Proceedings, Composite Construction in steel and concrete IV, ASCE, Reston, Virginia, 2002.

[12] Associação Brasileira de Normas Técnicas. ABNT NBR 8681:2003: ações e segurança nas estruturas - procedimento. Rio de Janeiro, 2003. (versão corrigida: 2004).

[13] Associação Brasileira de Normas Técnicas. ABNT NBR 6120:1980: cargas para cálculo de estruturas de edificações - procedimento. Rio de Janeiro, 1980 (versão corrigida: 2000).

[14] Hong, H.P. and Zhou, W. 1999. Reliability evaluation of RC columns, Journal of Structural Engineering, ASCE, Vol. 125, No. 7, pp. 784-790. Melchers, 1999.

[15] Nowak, A. S.; Szerszen, M. Calibration of design code for buildings (ACI 318): Part 1 - Statistical models for resistance. ACl structural Journal, New York, v. 100 , n. 3, p. $377-$ 382, 2003. 